The International Journal of Multimedia \& Its Applications (IJMA) Vol.10, No.6, December 2018

\title{
Creativity Of Student As A Game Designer: AN EXPLORATORY STUDY
}

\author{
Azimah Khairulamin and Laili Farhana Md Ibharim \\ Department of Computing, Faculty of Art, Computing \& Industry Creative, \\ Sultan Idris Education University, Malaysia
}

\begin{abstract}
Technological acceleration and educational gameplay response among community educators, students and communities today are seen to nurture creativity in line with 21 st century educational needs. Thus, the purpose of this study is to analyse the element of creativity of the students who act a sa designer in the process of board game design. This study focuses on four aspects of creativity namely originality, flexibility, fluency and elaboration. The research design is quantitative using observation method to obtain a thorough findings. The data were collected through a checklist involving 32 secondary school students in Kinta district. The findings of this study show that students are able to produce games based on their own creativity that possesses elements of originality, flexibility, fluency and elaboration. As a conclusion, this research shows that students are not only playing, but they are also able to generate an open mind while playing games.
\end{abstract}

\section{KEYWORDS}

Creativity, Student as a game designer, Board Game

\section{INTRODUCTION}

Creativity is an added value that are needed in the students of this globalization era. [1] Researcher believed that creativity is not the natural quality only for those who are selected. Creativity exists in every human being and it can be learned, practiced and developed by using techniques by experts who have proven to enhance and stimulate creative abilities. Malaysia Education Blueprint 2013-2025 [2] states that creativity has become an important aspect of generating creative and innovative thinking in which creativity is defined as being able to innovate, generate new possibilities, and create new ideas or knowledge. Meanwhile, [3] Torrance defined creativity as the capacity to detect gaps, propose various solutions to solve problems, produce novel ideas, re-combine them, and intuit a novel relationship between ideas.

In terms of dimensions, [4] Guilford and Torrance have defined and consolidated different processes that have been universally assumed in the assessment of creativity: fluency (production of ideas), flexibility (production of different ideational categories), originality (production of unusual ideas), and elaboration (persistency on introducing details to products). The main question is, can creativity be measured? Based on the previous research by Piffer [5], the sum of the creativity scores of all the products generated by a person represents that person's creativity. This shown that creativity can be measured using a proper indicator that describing the definition of the creativity itself such Torrance Tests of Creative Thinking, Remote Associates Test, Test for Creative Thinking Drawing Production and much more. [6] The Curriculum Development Division in Ministry of Education has also developed the Creativity Handbook: Development and Practice in Learning and Teaching as a teacher reference to understand the concept of creativity and to plan learning that motivates students to be more active, creative and critical thinking in along with the development of technology and the education system in Malaysia. It is one of the

DOI: $10.5121 /$ ijma.2018.10609 
The International Journal of Multimedia \& Its Applications (IJMA) Vol.10, No.6, December 2018

shifts in the transformation of the national education system in an effort to leverage Information and Communication Technology (ICT) to improve the quality of self-directed based learning. From the aspect of education among educator communities, students and societies today are seen to foster creativity in line with 21 st century educational needs that emphasize the evolution of technology.

The rapid development of ICT in education is said to have brought a change in the way of how students learn. This game-based learning approach has begun to be accepted by educators in order to create an effective and fun learning environment. Game-based learning is a form of studentcentred learning that uses digital games for educational purposes [7]. The digital game in education is a kind of learning medium that enables students to build meaning and understanding in every phase of learning [8]. The game-based learning approach has the potential to strengthen the learning and facilitating process with the support of pedagogical approaches implemented in the classroom especially from the aspect of student creativity. According to Baytak, Susan \& Smith and Karadag [9] [10] game-based learning can promote positive attitudes towards learning and developing memory skills, and have potential in fostering relationships between students as well as helping them to build self-learning. Furthermore, digital game is not the only medium that can be used for learning purpose. The other medium that can be used in game-based learning is a board game.

Board games are innovative educational tools that can enhance active learning using a physical game such as Monopoly, Scrabble, Snakes and Ladder, and much more [11]. This learning method suitable for students that does not have facilities such as computer in their class room. There is various types of board game such as abstract strategy games (e.g. chess, checkers and Go), alignment games (e.g. Tic-tac-toe), multiplayer games (e.g. Risk, Monopoly, or Four-player chess), single-player puzzle games (e.g.peg solitaire or Sudoku), paper-and-pencil games (e.g. Tic-tac-toe or Dots and Boxes), tile-based games (e.g. Carcassonne, Scrabble, Tigris and Euphrates, or Evo) and much more. This variation of board games offer students the opportunity to improve memory skill, problem-solving skill, counting, learn more about knowledge and word recognition. However, this game only gives students the opportunity to communicate and play only, what if we (educator and parents) let them build their own games in creative ways?

The growth of technology and the acceptance of gamification in education among educator communities, students and society today is seen to nurture creativity in line with 21 st century's education needs. Therefore, through this study, the researcher wants to explore the aspect of creativity of student that integrating the technology in game design. This study aims to analyze the elements of creativity of students as designers in the design process of board games. This study focuses on four aspects of creativity namely i) originality; ii) flexibility; iii) fluency; and iv) elaboration during the board game design process.

\section{Methodology}

The main purpose of the study was to explore the creativity of students based on the theory of creativity Paul E. Torrance in the aspect of originality, flexibility, fluency and elaboration during the process of board game design. The research design used in this study is qualitative design. In this study, the researcher used observation method to explore the creativity of the students who act as designers during the board game design process.

A total of 32 high school students who were divided into eight groups participated in the study as participants of the Tabletop Game Design competition. Participants consist of high school 
The International Journal of Multimedia \& Its Applications (IJMA) Vol.10, No.6, December 2018 students aged between 14 and 16 years old lived around Kinta district. A total of 14 people comprising academic experts and industry practitioners were involved as evaluators to evaluate students' creativity during the board game design process using expert checklists.

Competition-based team concept [12] is the basis for ensuring that this activity is aligned with the objectives of the study. The assignment given for this research is they need to produce an environmentally themed prototype. The chosen theme was supposed to expose students to new learning and to apply moral values in the student. The competition was held for two days at the Dewan Risda, Ipoh. The process of research design that used is a game-based learning approach through the game design process and it was used as the basis for the study. During the test session, the researcher applied the Game Making Pedagogy model [13] to create learning environment through board game design activity which clearly shows that this combination is compatible with the purpose of the study. Based on the Game Making Pedagogy model, activities carried out during the learning and teaching process take place through seven levels such as Table 1.

Table 1. Activity procedures based on the Game Making Pedagogy Model.

\begin{tabular}{|l|l|l|}
\hline Day & \multicolumn{1}{|c|}{ Level } & \multicolumn{1}{c|}{ Activities } \\
\hline \multirow{3}{*}{ One } & Topic exploration & $\begin{array}{l}\text { Find information on board games and environmental } \\
\text { issues }\end{array}$ \\
\cline { 2 - 3 } & Knowledge acquisition & $\begin{array}{l}\text { Observe, select and manipulate the materials provided } \\
\text { to build board games }\end{array}$ \\
\cline { 2 - 3 } & Goal Setting & $\begin{array}{l}\text { Discussions of group members in designing game } \\
\text { designs through storyboards and sketches }\end{array}$ \\
\hline \multirow{2}{*}{ Two } & Content creation & Create and develop board games \\
\cline { 2 - 3 } & Component synthesis & Perform first test of the game that has been designed \\
\cline { 2 - 3 } & Peer survey & $\begin{array}{l}\text { Try each game from another group and give feedback } \\
\text { for improvement review }\end{array}$ \\
\cline { 2 - 3 } & Testing & $\begin{array}{l}\text { Presents the final design of the board game produced } \\
\text { to be evaluated by the evaluator }\end{array}$ \\
\hline
\end{tabular}

Figure 2, 3, 4 and 5 shows that the activities carried out during the competition based on Game Making Pedagogy Model. During this competition, the student can only use the materials that been provided by the researcher as Figure 1. This is the limitation that have been set by the researcher. The data is collected using a checklist of analysis of student creativity in game design that consist of items as shown below:

Originality:

1) The idea of game design which contributed from participant is unique.

2) The idea of game design which contributed from participant is novel.

3) The idea of game design which contributed from participant is infrequent.

4) The idea of game design which contributed from participant is extraordinary.

Fluency:

1) The idea of game design which contributed from participant is logic.

2) The idea of game design which contributed from participant is relevant.

3) The idea of game design which contributed from participant is continuous.

4) The idea of game design which contributed from participant is meaningful.

5) The idea of game design which contributed from participant is expected. 
The International Journal of Multimedia \& Its Applications (IJMA) Vol.10, No.6, December 2018

Flexibility:

1) The idea of game design which contributed from participant is can be variety.

2) The idea of game design which contributed from participant is can be modify.

3) The idea of game design which contributed from participant is can be exaggerate.

Elaboration:

1) The idea of game design which contributed from participant is interpretable.

2) The idea of game design which contributed from participant is easy to understand.

3) The idea of game design which contributed from participant is organize well.

4) The idea of game design which contributed from participant is specific.

These items are combination of element of creativity by Torrance [3] and creative thinking indicator in Creativity Handbook: Development and Practice in Teaching \& Learning by Ministry of Education [6].
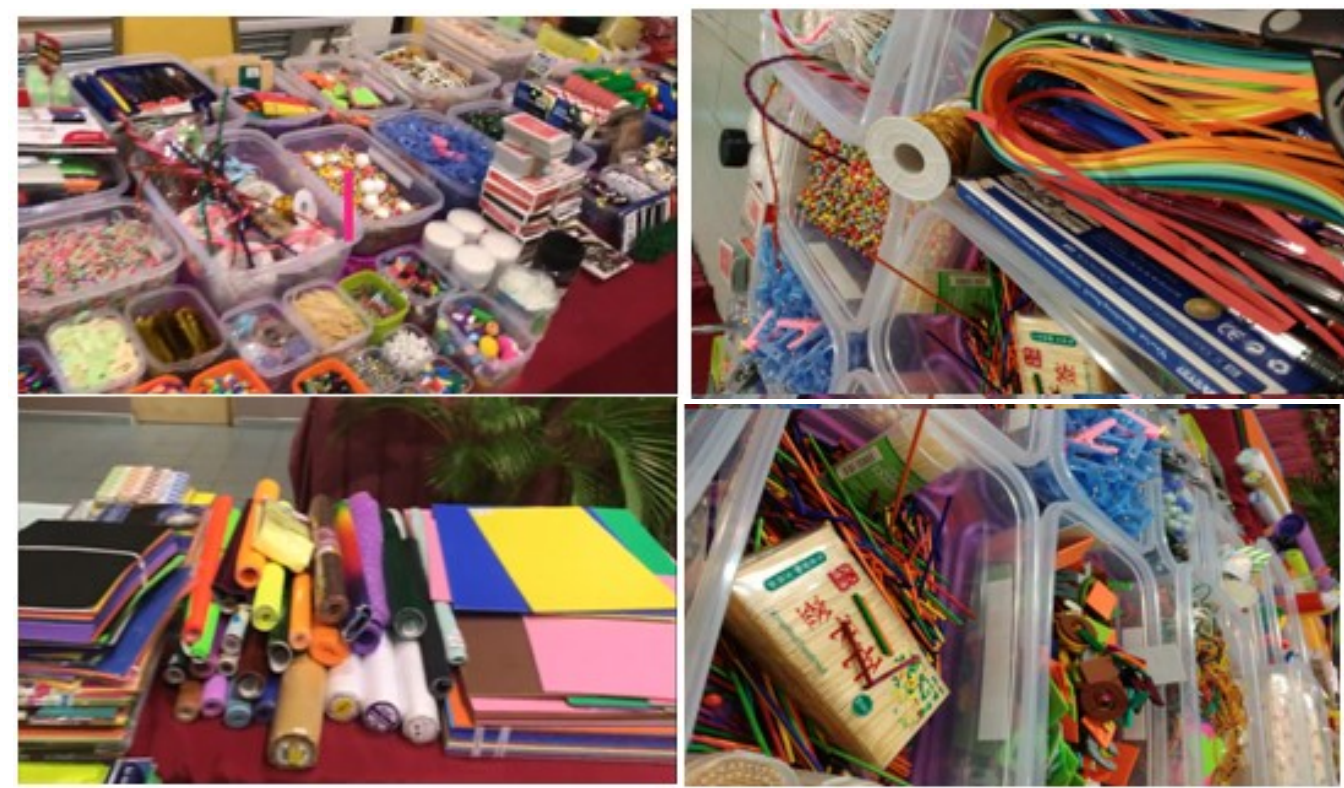

Figure 1: Materials

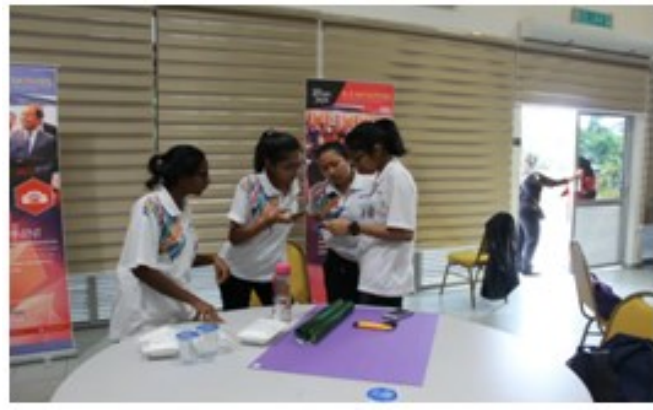

Figure 2: Topic exploration

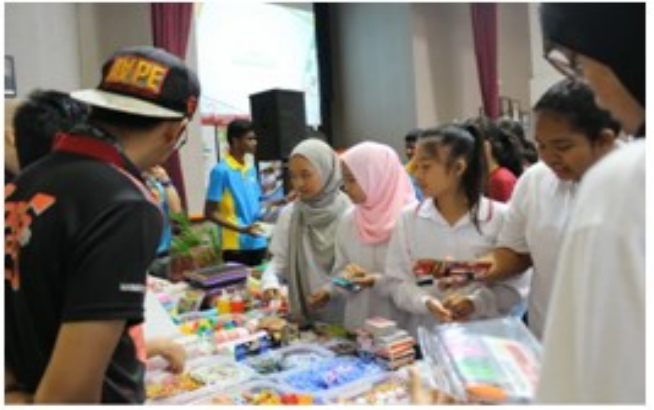

Figure 3: Knowledge acquisition 


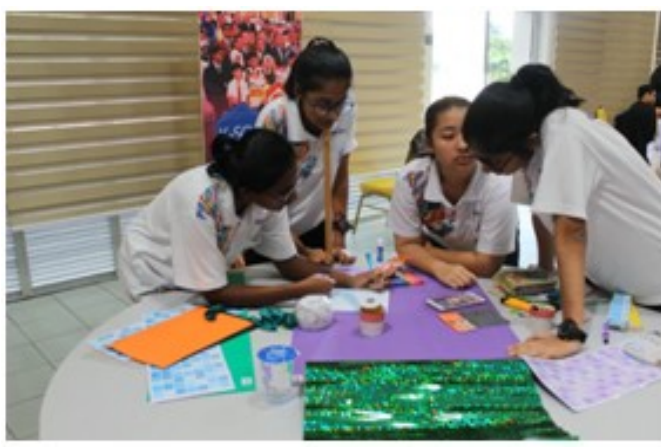

Figure 4: Content creation

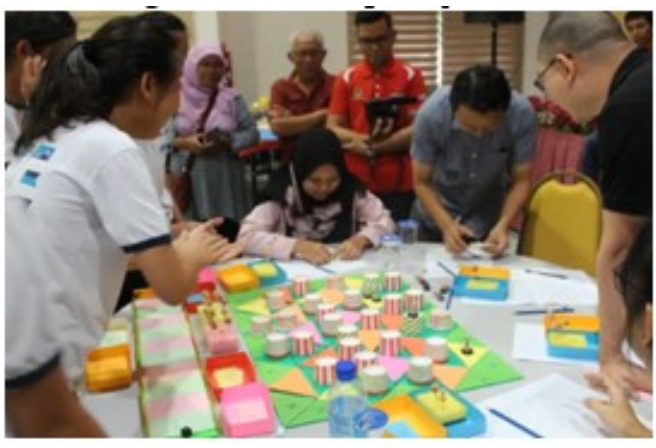

Figure 5: Testing and judging Session

\section{RESULTS AND DISCUSSION}

Table 3. Analysis aspect of originality.

\begin{tabular}{|c|c|c|c|c|c|c|c|c|c|c|c|c|c|}
\hline \multirow{3}{*}{ Aspect } & \multirow{3}{*}{ Group } & \multicolumn{12}{|c|}{ Item ( $n=$ number of evaluator) } \\
\hline & & \multicolumn{3}{|c|}{ Unique } & \multicolumn{3}{|c|}{ Novel } & \multicolumn{3}{|c|}{ Infrequent } & \multicolumn{3}{|c|}{ Extraordinary } \\
\hline & & $\mathrm{A}$ & NS & NA & $\mathrm{A}$ & NS & $\mathrm{NA}$ & $\mathrm{A}$ & NS & NA & A & NS & NA \\
\hline \multirow{8}{*}{ Originality } & 1 & 9 & 3 & 2 & 7 & 3 & 4 & 8 & 5 & 1 & 3 & 6 & 5 \\
\hline & 2 & 5 & 7 & 2 & 3 & 6 & 5 & 3 & 7 & 4 & 5 & 4 & 5 \\
\hline & 3 & 13 & 0 & 1 & 13 & 0 & 1 & 9 & 4 & 1 & 10 & 3 & 1 \\
\hline & 4 & 9 & 3 & 2 & 8 & 2 & 4 & 8 & 4 & 2 & 7 & 5 & 2 \\
\hline & 5 & 12 & 0 & 2 & 11 & 0 & 3 & 8 & 3 & 3 & 7 & 3 & 4 \\
\hline & 6 & 7 & 3 & 4 & 7 & 3 & 4 & 4 & 6 & 4 & 4 & 4 & 6 \\
\hline & 7 & 12 & 2 & 0 & 10 & 3 & 1 & 12 & 1 & 1 & 9 & 5 & 0 \\
\hline & 8 & 11 & 1 & 2 & 9 & 2 & 3 & 9 & 3 & 2 & 8 & 2 & 4 \\
\hline
\end{tabular}

Note: $\mathrm{A}=$ Agree, $\mathrm{NS}=$ Not Sure and NA=Not Agree

As for the aspect of originality as in Table 2, the majority of the evaluators agree that seven groups show unique and new features on the game designs produced except for the group 2 . Unique and novel can be seen in game designs that feature own designs. The design of the games meet the requirement for themes and objectives similarly to a board game named 'The Last Mountain' (in Figure 6) that shows a unique feature with 3D board game form and creates new characters 'Protector' and 'Destroyer' to players.

The evaluator's assessment also agreed that six groups produced infrequent design features except in group 2 and group 6. Evaluators argued that the design of board games produced was rarely found in the market and six groups were also certified by the evaluator's evaluation that the designs produced have not been published before and it's increasingly exciting when these design ideas came from high school students. Data shows that the aspects of originality are the most important aspects in translating the creativity of students in the terms of design [14] have also conducted a study and found that the construct of originality is an essential component of creativity. 
The International Journal of Multimedia \& Its Applications (IJMA) Vol.10, No.6, December 2018

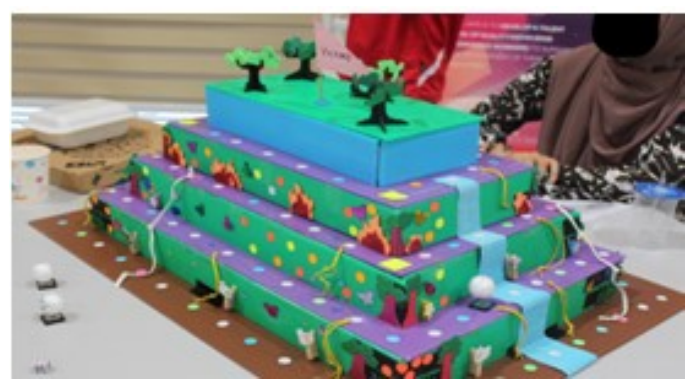

Figure 6: Board Game 'The Last Mountain'

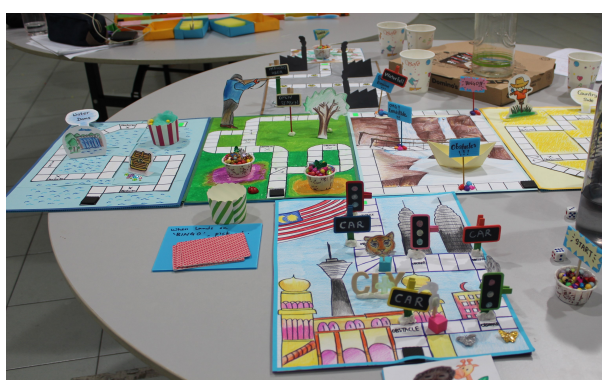

Figure 7: Board Game 'Escape'

Table 4. Analysis aspect of fluency.

\begin{tabular}{|c|c|c|c|c|c|c|c|c|c|c|c|c|c|c|c|c|}
\hline \multirow{3}{*}{ Aspect } & \multirow{3}{*}{ Group } & \multicolumn{15}{|c|}{ Item ( $n=$ number of evaluator) } \\
\hline & & \multicolumn{3}{|c|}{ Logic } & \multicolumn{3}{|c|}{ Relevant } & \multicolumn{3}{|c|}{ Continuous } & \multicolumn{3}{|c|}{ Meaningful } & \multicolumn{3}{|c|}{ Expected } \\
\hline & & A & $\begin{array}{l}\mathrm{N} \\
\mathrm{S}\end{array}$ & $\begin{array}{l}\mathrm{N} \\
\mathrm{A}\end{array}$ & A & $\begin{array}{l}\mathrm{N} \\
\mathrm{S}\end{array}$ & $\begin{array}{l}\mathrm{N} \\
\mathrm{A}\end{array}$ & A & NS & NA & A & $\begin{array}{l}\mathrm{N} \\
\mathrm{S}\end{array}$ & $\begin{array}{l}\mathrm{N} \\
\mathrm{A}\end{array}$ & A & NS & $\begin{array}{l}\mathrm{N} \\
\mathrm{A}\end{array}$ \\
\hline \multirow{8}{*}{ Fluency } & 1 & 4 & 6 & 4 & 2 & 8 & 4 & 0 & 9 & 5 & 2 & 7 & 5 & 7 & 3 & 4 \\
\hline & 2 & 7 & 4 & 3 & 6 & 4 & 4 & 6 & 5 & 3 & 5 & 6 & 3 & 10 & 2 & 2 \\
\hline & 3 & 9 & 3 & 2 & 12 & 2 & 0 & 9 & 4 & 1 & 10 & 4 & 0 & 8 & 4 & 2 \\
\hline & 4 & 11 & 1 & 2 & 12 & 1 & 1 & 10 & 2 & 2 & 9 & 4 & 1 & 9 & 2 & 3 \\
\hline & 5 & 11 & 1 & 2 & 12 & 0 & 2 & 9 & 2 & 3 & 7 & 4 & 3 & 8 & 2 & 4 \\
\hline & 6 & 7 & 3 & 4 & 4 & 4 & 6 & 6 & 4 & 4 & 4 & 6 & 4 & 8 & 4 & 2 \\
\hline & 7 & 13 & 1 & 0 & 9 & 5 & 0 & 9 & 5 & 0 & 11 & 3 & 0 & 9 & 4 & 1 \\
\hline & 8 & 9 & 2 & 3 & 11 & 2 & 1 & 5 & 8 & 1 & 7 & 5 & 2 & 9 & 1 & 4 \\
\hline
\end{tabular}

Note: $\mathrm{A}=$ Agree, $\mathrm{NS}=$ Not Sure and $\mathrm{NA}=$ Not Agree

For fluency aspects as in Table 3, the majority of the evaluators agree that seven group exhibit a logical feature on the design of the game produced except for the group 1 . The logical features can be seen in game designs that justify each layout and object used in the design. The designs of the six groups recognized by the evaluator team to have the suitable and persistent features for example, the board game design created by the group 5, Escape (in figure 7), which presents a diverse range of games including a healthy and polluted environment. This idea is suitable to the way of how players play (animal characters) to go through each zone to escape from the zoo to the jungle. The element of the game which is storytelling continuously helps players to develop their knowledge to craft strategies for passing through each zone.

Next, the five groups show a meaningful design feature that has an impact in terms of changes in understanding and the civic awareness of players towards environmental care. The majority of evaluators state that the design of all groups has a predictable feature which means the players are

able to find out every feedback such as rewards or penalties during play. This is to ensure that the board games still can be played even though the players are playing the games for the first time. The data obtained from the aspect of fluency shows that the design has the features that enable this game board to be played which also innovative factor was composed from the fluency and originality abilities stated by Torrance [15]. 
The International Journal of Multimedia \& Its Applications (IJMA) Vol.10, No.6, December 2018

Table 5. Analysis aspect of flexibility.

\begin{tabular}{|c|c|c|c|c|c|c|c|c|c|c|}
\hline \multirow{3}{*}{ Aspect } & \multirow{3}{*}{ Group } & \multicolumn{9}{|c|}{ Item ( $n=$ number of evaluator) } \\
\hline & & \multicolumn{3}{|c|}{ Various } & \multicolumn{3}{|c|}{ Can Be Modify } & \multicolumn{3}{|c|}{ Can Be Exaggerate } \\
\hline & & A & NS & NA & A & NS & NA & A & NS & $\mathrm{N}$ \\
\hline \multirow{8}{*}{ Flexibility } & 1 & 6 & 3 & 5 & 6 & 5 & 3 & 4 & 7 & 3 \\
\hline & 2 & 9 & 3 & 2 & 6 & 5 & 3 & 5 & 7 & 2 \\
\hline & 3 & 12 & 2 & 0 & 8 & 5 & 1 & 10 & 4 & 0 \\
\hline & 4 & 11 & 1 & 2 & 10 & 2 & 2 & 11 & 2 & 1 \\
\hline & 5 & 11 & 1 & 2 & 11 & 2 & 1 & 9 & 4 & 1 \\
\hline & 6 & 7 & 4 & 3 & 6 & 3 & 5 & 6 & 4 & 4 \\
\hline & 7 & 9 & 2 & 3 & 7 & 4 & 3 & 8 & 4 & 2 \\
\hline & 8 & 4 & 7 & 3 & 7 & 5 & 2 & 8 & 2 & 4 \\
\hline
\end{tabular}

Note: $\mathrm{A}=$ Agree, $\mathrm{NS}=$ Not Sure and $\mathrm{NA}=$ Not Agree

For the flexibility aspect as in Table 4, the majority of the evaluators agree that seven groups exhibit multiple features on game designs except group 8 which using repetitive objects, layouts and the instruction on how to play the game. This diversity feature allows each group to make modifications to the design whether in terms of object, game or game rules as agreed by the majority of the evaluator. Nevertheless, only six groups managed to convince evaluators that the design of the board games can be modified where developer can develop challenges in order to make the game more difficult and exciting. Good games should consider both the learning goals/content and the game play at the same time, with enough flexibility to iterate between the two to change one or both simultaneously [16].

The various and exaggerated design features can be seen on group 4's board games called 'Catch Me Not' in Figure 8. In this board game, there are three types of missions which is the first mission where players have to reach the finishing line. The second mission is player need to guess who is the player who plays the character of the owner of the factory that destroys the environment (called 'Polluter') and the last mission is the player needs to stop the 'Polluter' from reaching the finishing line. This aspect of flexibility makes the designers more creative, as they can test the diversity of creative ideas based on different perspectives, strategies and approaches [6].

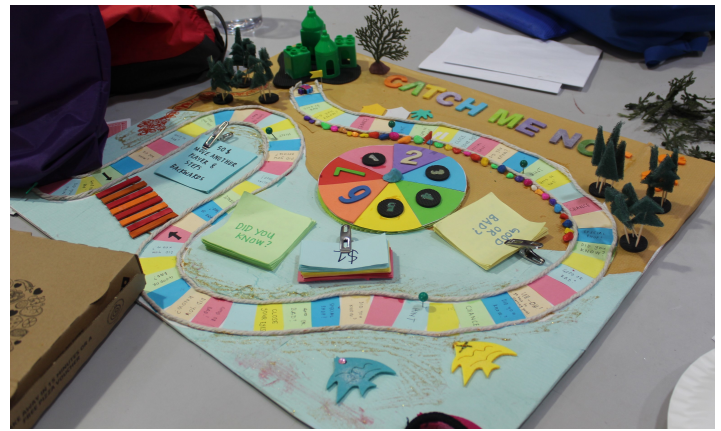

Figure 8: Board Game 'Catch Me Not'

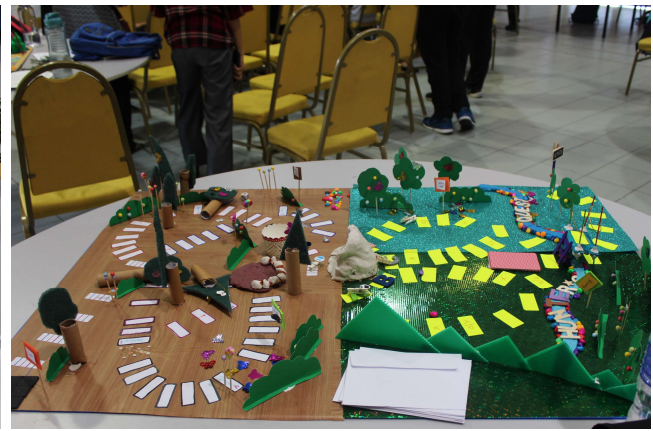

Figure 9: Board Game 'The Hunter Quest' 
The International Journal of Multimedia \& Its Applications (IJMA) Vol.10, No.6, December 2018

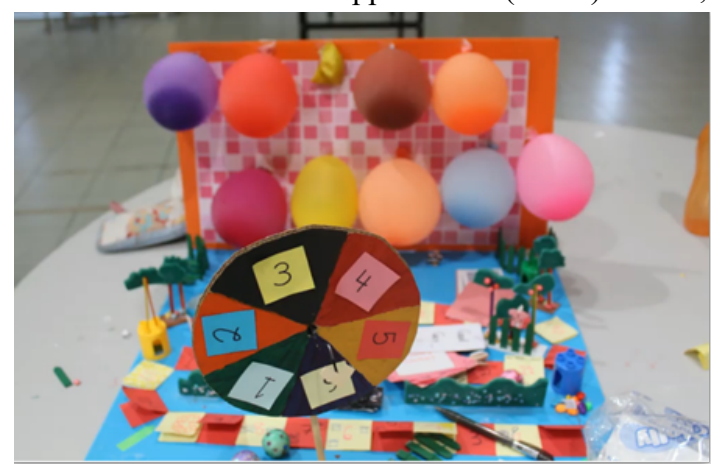

Figure 10: Board Game 'Million Environment Ladder'

Table 6. Analysis aspect of elaboration.

\begin{tabular}{|c|c|c|c|c|c|c|c|c|c|c|c|c|c|}
\hline \multirow{3}{*}{ Aspect } & \multirow{3}{*}{ Group } & \multicolumn{12}{|c|}{ Item ( $n=$ number of evaluator) } \\
\hline & & \multicolumn{3}{|c|}{ Interpretable } & \multicolumn{3}{|c|}{ Understandable } & \multicolumn{3}{|c|}{ Organize } & \multicolumn{3}{|c|}{ Specific } \\
\hline & & A & NS & NA & A & NS & NA & A & NS & NA & A & NS & $\begin{array}{l}\mathrm{N} \\
\mathrm{A}\end{array}$ \\
\hline \multirow{8}{*}{$\begin{array}{l}\text { Elaborati } \\
\text { on }\end{array}$} & 1 & 8 & 4 & 2 & 7 & 6 & 1 & 6 & 4 & 4 & 5 & 4 & 5 \\
\hline & 2 & 6 & 7 & 1 & 6 & 7 & 1 & 5 & 4 & 5 & 9 & 4 & 1 \\
\hline & 3 & 9 & 3 & 2 & 9 & 4 & 1 & 10 & 2 & 2 & 8 & 5 & 1 \\
\hline & 4 & 12 & 1 & 1 & 12 & 2 & 0 & 11 & 3 & 0 & 13 & 1 & 0 \\
\hline & 5 & 9 & 5 & 0 & 13 & 1 & 0 & 9 & 3 & 2 & 9 & 3 & 2 \\
\hline & 6 & 10 & 4 & 0 & 9 & 4 & 1 & 6 & 4 & 4 & 9 & 2 & 3 \\
\hline & 7 & 12 & 2 & 0 & 12 & 1 & 1 & 13 & 1 & 0 & 11 & 3 & 0 \\
\hline & 8 & 8 & 4 & 2 & 9 & 4 & 1 & 9 & 2 & 3 & 7 & 5 & 2 \\
\hline
\end{tabular}

Note: $\mathrm{A}=$ Agree, $\mathrm{NS}=$ Not Sure and $\mathrm{NA}=$ Not Agree

In terms of elaboration as in Table 5, the majority of the evaluators agree that seven groups show features that are easily to interpret into game designs except group 2 (board game 'Million Environment Ladder' in Figure 10) that produce deceptive and unorganized board games. Based on Figure 10, the developer tried to show the variety of games such as pop-out the balloon, roll the dice to take turn, and spin the wheel. However, the outcome from this variation makes this game unorganized and hard to predict on how to play it.

The Hunter Quest board game (on Figure 9) designed by group 6 shows examples of features that interpretable, understandable and organize similarly to board game named 'Jutaria

Millionaire'. However, the board game was modified to be more interesting. Therefore, even without reading the instruction on how to play the game, players are still aware and understand the storyline of the game. In fact, based on those existing board games, this group is able to parse their own ideas and add details to make the board game more useful and relevant. Specific features in the aspect of elaboration are agreed upon by the majority of the evaluators because the design of the game has a special purpose and a not-so-diverse idea that causes the board to be complex and unsuitable by certain range of age. Based on this data, student creativity is analysed through their ability to solve problems by combining several ideas into one and being exhibited easily as Torrance states [17]. 
The International Journal of Multimedia \& Its Applications (IJMA) Vol.10, No.6, December 2018

\section{CONCLUSiOn AND Future Work}

\subsection{Conclusion}

The results of this study showed that the students successfully highlighted creativity in the design of board games which were seen to be expanded in the game industry. Although the students does not have the basic design of the game, the result of the 2-day design process is amazing. Theory of creativity that consists of aspects of originality, flexibility, fluency and elaboration can be seen through the results of their products. The originality aspect is the most prominent aspect that can be seen in the board games which have been built. As a further matters, the majority of the evaluators have agreed that almost all board game designs are unique. Although there are several designs that using existing board game as a references, however, it does not impeded student creativity to manipulate ideas in producing new board games. In addition, flexibility aspect does not limit students from using and applying existing knowledge during the design process and further encouraging students to think creatively and critically.

The creativity of the students in the fluency aspect has also been proven by the emergence of logical board games and is in line with the predetermined theme of the environment. Students succeeded in linking current issues regarding environmental pollution and providing solutions to the issue in the form of board games. They do not even want to play, but they can even solve their problems as well as educating the community. Similarly, the elaboration aspect was seen with the creation of a board game that is organized and easy to understand in terms of design, method and objective of the game, as well as storytelling and knowledge. Their ability to deliver messages through this game demonstrates that learning and teaching not only happens in the classroom, but also can be done anywhere through the game design process.

This suggests that creativity in the game design process can have a positive effect on the students in terms of learning in line with the Ministry of Education's desire which focuses on creativity in 21st Century Learning (PAK21). Educators and parents assume that games as a negative thing [18] but based on this research, students are not only playing, but they are also able to build games that can generate an open mind. As we can see from this research, [19] children's learning through making their own games. Researchers also believed that game based learning is effective in nurturing children's positive learning and prosocial behaviours [20], can sharpen the talent and creativity of students in addition to produce quality and skilled students.

\subsection{FUTURE WORK}

This paper focuses on the use of board games as a medium to measure students' creativity and they are measured using checklists. There are some ideas that researcher wants to put forward for future research. The following ideas can be used as a future study:

1. Develope a rubric of creativity of student as a game designer. Researcher can use the same checklist used in this study as reference or build rubric based on relevant specialist instruments.

2. Evaluate a student creativity in the process of designing a digital game. The following study allows researchers to analyze the element of creativity of children as designers in digital game design process using Scratch software.

\section{ACKNOWLEDGEMENT}

This research is sponsored by the Ministry of Education Malaysia under the grant of the Fundamental Research Grant Scheme (FRGS), 2017-0072-107-02. 
The International Journal of Multimedia \& Its Applications (IJMA) Vol.10, No.6, December 2018

\section{REFERENCES}

[1] Aqda, M. F., Hamidi, F., \& Ghorbandordinejad, F. (2011). The impact of constructivist and cognitive distance instructional design on the learner's creativity. Procedia computer science, 3, 260-265.

[2] Kementerian Pendidikan Malaysia. (2013). Laporan Awal Pelan Pembangunan Pendidikan Malaysia 2013-2025. Retrieved from http://www.moe.gov.my/userfiles/file/PPP/Preliminary-Blueprint-BM.pdf.

[3] Torrance, E. P. (1969). Creativity. What research says to the teacher. Washington, DC: National Education Association.

[4] Almeida, L. S., Prieto, L. P., Ferrando, M., Oliveira, E., \& Ferrándiz, C. (2008). Torrance Test of Creative Thinking: The question of its construct validity. Thinking skills and creativity, 3(1), 53-58.

[5] Piffer, D. (2012). Can creativity be measured? An attempt to clarify the notion of creativity and general directions for future research. Thinking Skills and Creativity, 7(3), 258-264.

[6] Kementerian Pelajaran Malaysia. (2011). Buku panduan kreativiti: Pembangunan dan amalan dalam pengajaran dan pembelajaran. KL: Bahagian Pembangunan Kurikulum.

[7] W. H. Tan, S. Johnston-Wilder, and S. Neill, Examining the potential of game -based learning through the eyes of maths trainee teachers. Proc. Br.Soc. Res. into Learn. Math., vol. 28, no. 3, pp. $120-124,2008$.

[8] K. Yilmaz, Social studies teachers' views of learner-centered instruction. Eur. J. Teach. Educ., vol. 31, no. 1, pp. $35-53$, Feb. 2008.

[9] Baytak, A., Susan, M. L., \& Smith, B. K. (2011). Children as educational computer game designers: An exploratory study. TOJET: The Turkish Online Journal of Educational Technology, 10(4).

[10] Karadag, R. (2015). Pre-Service Teachers' Perceptions on Game Based Learning Scenarios in Primary Reading and Writing Instruction Courses. Educational Sciences: Theory and Practice, 15(1), 185200.

[11] Yoon, B., Rodriguez, L., Faselis, C. J., \& Liappis, A. P. (2014). Using a board game to reinforce learning. The Journal of Continuing Education in Nursing, 45(3), 110-111.

[12] Chen, C. H., \& Hwang, G. J. (2017). Effects of the team competition-based ubiquitous gaming approach on students' interactive patterns, collective efficacy and awareness of collaboration and communication. Journal of Educational Technology \& Society, 20(1), 87.

[13] Cheng, G. (2009). Using game making pedagogy to facilitate student learning of interactive multimedia. Journal of Educational Technology, 25(2), 204-220.

[14] Acar, S., Burnett, C., \& Cabra, J. F. (2017). Ingredients of creativity: Originality and more, Creativity Research Journal, 29(2), 133-144.

[15] Torrance EP. An Interview with E. Paul Torrance: About Creativity. Journal Education Psychology. 1998; 10(4): 441-52

[16] Burke, Q., \& Kafai, Y. B. (2014). Decade of game making for learning: From tools to communities". Handbook of digital games, 689-709.

[17] Baer, J. (2016). Creativity doesn't develop in a vacuum. New directions for child and adolescent development, 2016(151), 9-20.

[18] Nasir Masran, Md \& M.I., Laili Farhana \& Yatim, Maizatul. (2014). Pendekatan Pembelajaran Melalui Reka Bentuk Permainan Digital dalam Proses Pengajaran dan Pembelajaran Kanak-kanak: Isu dan Cabaran. International Conference on Education Technology.

[19] Kafai, Y. B., \& Burke, Q. (2015). Constructionist gaming: Understanding the benefits of making games for learning. Educational psychologist, 50(4), 313-334.

[20] Chin, L. C., \& Zakaria, E. (2015). Effect of Game-Based Learning Activities on Children's Positive Learning and Prosocial Behaviours (Kesan Aktiviti Pembelajaran Berasaskan Permainan terhadap Pembelajaran Positif dan Tingkah Laku Prososial Kanak-Kanak). Jurnal Pendidikan Malaysia (Malaysian Journal of Education), 40(2), 159-165. 
The International Journal of Multimedia \& Its Applications (IJMA) Vol.10, No.6, December 2018

\section{AUTHORS}

Nur Azimah Khairulamin is currently pursuing a Master in Design (Game Based Learning) at Faculty of Art, Computing and Creative Industries, Sultan Idris Education University, Malaysia. She previously holds a Bachelor's Degree in Education (Multimedia) at the same university. She is particularly interested in conducting research on technology in education primarily involving the efficient use of technology in teaching and learning.

Laili Farhana Md Ibharim who is currently in Faculty of Art, Computing and Creative Industry, Sultan Idris Education University has been a lecturer for almost 3 years. She has extensive experience in Gamification, Multimedia and Digital Games in Education. She holds a Bachelor of Information Technology (Multimedia) from University of Malaya. Subsequently, she obtained a Master of Education (Multimedia) and Doctor of Philosophy in Education Multimedia from Sultan Idris Education University, Malaysia.
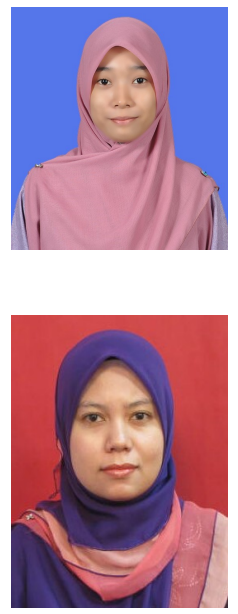